\title{
FREQUENCY OF FUNDAL VARICES IN CIRRHOTIC PATIENTS WITH UPPER GASTROINTESTINAL BLEED.
}

1. MBBS, FCPS Medicine, FCPS Gastroenterology

Assistant Professor

Department of Gastroenterology

Nishtar Medical University, Multan.

2. MBBS, MD (USA), MRCP (UK) MRCP (London), ESEGH (UK),

Fellow of Gastroenterology

Nishtar Medical University, Multan.

3. MBBS

House Officer

Benazir Bhutto Hospital, Rawalpindi.

4. MBBS

House Officer

Ibn-E-Siena Hospital, Multan.

5. MBBS

Resident

Department of Hematologist,

CMH Multan

Correspondence Address: Dr. Waseem Sarwar Malghani

Department of Gastroenterology

Nishtar Medical University, Multan

malghanidr@gmail.com

Article received on:

21/01/2019

Accepted for publication:

$15 / 06 / 2019$

Received after proof reading:

30/09/2019

\begin{abstract}
Waseem Sarwar Malghani', Farooq Mohyud Din Chaudhary ${ }^{2}$, Asim Tameez Ud Din ${ }^{3}$,
\end{abstract} Sana Mohyud Din Chaudhary ${ }^{4}$, Asma Tameez Ud Din ${ }^{5}$

ABSTRACT... Objectives: Acute upper gastrointestinal bleeding (AUGIB) is a common medical emergency in cirrhosis. These patients mainly bleed from esophageal varices. The aim of the present work was to determine the prevalence of fundal varices; gastro-oesophageal varices type2 (GOV-2) and isolated gastric varices type1 (IGV-1), as a cause of AUGIB. Study Design: Cross-sectional study. Setting: Gastroenterology Department of Nishtar Hospital Multan, Pakistan, using non-probability consecutive sampling. Period: July to December 2018. Material and Methods: Emergency upper gastrointestinal (UGI) endoscopy was performed in 165 cirrhotic patients and the findings documented. Results: The mean age was $50.15 \pm 12.72$ years. There were $103(62.4 \%)$ males and 62 (37.6\%) females $(p<0.0001)$. Hepatitis $C$ virus (HCV) was the cause of cirrhosis in $75 \%$, followed by HBV in $10 \%$ and HBV \& HCV co-infection in $6 \%$. Bleeding fundal varices were found in 25 (15\%) patients, 15 IGV-1 and 10 GOV-2. Other major causes of bleeding included: esophageal varices $93(56.4 \%)$ and portal hypertensive gastropathy (PHG) 33 (20\%). All fundal varices were found in advanced liver disease patients $(p<0.05)$. Conclusion: AUGIB is more common in males and advance liver disease. Although not frequent, fundal varices are an important cause of AUGIB, with a strong association with severity of cirrhosis. Our study demonstrates a higher prevalence of fundal varices (especially IGV-1) than other studies.

Key words: $\quad$ Cirrhosis, Fundal Varices, Portal Hypertension, Upper Gastrointestinal Bleeding.

Article Citation: Malghani WS, Chaudhary FM, Tameez ud Din A, Chaudhary SM, Tameez ud Din A. Frequency of fundal varices in cirrhotic patients presenting with upper gastrointestinal bleed. Professional Med J 2019; 26(10):1655-1659. DOI: $10.29309 / T P M J / 2019.26 .10 .3164$

\section{INTRODUCTION}

The prevalence of acute upper gastrointestinal bleeding (AUGIB) is between 100-170 per 100,000 population. ${ }^{1,2,3}$ In the USA there are approximately 250,000 to 300,000 hospitalizations and an estimated 15,000 to 30,000 deaths per year as a result of AUGIB. ${ }^{4}$ AUGIB has an inpatient mortality rate of $10 \% .^{5}$ Even though there have been drastic improvement in methods of diagnosis and treatment, this mortality has remained unchanged

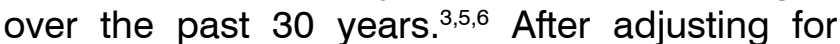
initial hospitalization, the mortality rate of AUGIB is similar to acute myocardial infarction $(0.64 \%$ versus $0.77 \%){ }^{7}$

Around $60-65 \%$ cases of AUGIB in cirrhotic patients are due to variceal bleeding. ${ }^{8}$ The severity of liver disease predicts the outcome of variceal bleeding. Child Class C patients have a $40 \% 6$ week mortality rate after a bleeding episode as compared to $0 \%$ mortality in Child Class A. ${ }^{9,10,11}$ Even though gastric varices are less common as compared to esophageal varices, they bleed more often. The purpose of our study was to investigate the frequency of fundal varices (IGV1 and GOV-2) as a cause of AUGIB in cirrhotic patients.

\section{METHODS}

This cross-sectional study was carried out from July to December 2018 at the Gastroenterology Department of Nishtar Hospital Multan, Pakistan using non-probability consecutive sampling. 
Patients undergoing emergency UGI endoscopy for first time episode of AUGIB (hematamesis or malena) were subjected to detailed history, examination and complete liver workup. A total of 165 cirrhotic patients were selected for study after taking informed consent. All those who did not give consent, pregnant females, patients having hepatocellular carcinoma or other malignancies, diabetes, hypertension were excluded.

The endoscopic findings were confirmed by a Consultant gastroenterologist having at least 3 years of post fellowship experience. The ChildTurcotte-Pugh (CTP) score was calculated for each patient and patients were classified according to CTP A, B or C. Gastric varices were identified according to the Sarin classification. ${ }^{12}$ Fundal varices were identified as IGV-1 (varices limited to fundus only) and GOV-2 (esophageal varices extending along the greater curvature to the fundus). The collected data was organized and analyzed using the SPSS version 20. A p value of $<0.05$ was considered significant.

\section{RESULTS}

Out of the total 165 patients, 103 were males and 62 were females $(p<0.0001)$. Mean age of our study was $50.15 \pm 12.72$ years. The mean age of males was $48.61+12.35$, while mean age of females was $52.72+13.04(p<0.005$, significant difference between the means). Minimum age of patients was 16 years and the maximum age 99 years. More than one third of patients belonged to the 41-50 years age group (Table-I). Hepatitis $C$ virus was the cause of cirrhosis in more than $75 \%$ of patients who had AUGIB, with $10 \%$ due to $\mathrm{HBV}$ and $6 \%$ due to both HBV and HCV. Non-viral cause of cirrhosis was only in 14 patients. Only 2 patients had history of alcoholism. As can be seen from Table-I, $83.6 \%$ cases of AUGIB occurred in decompensated liver disease patients (Child Class $B$ or $C$ ), while $17 \%$ cases were from Child Class A $(p<0.0001)$.

Fundal varices were found in 25 patients presenting with AUGIB, 15 of which were IGV-1 and 10 were GOV-2. All cases of bleeding fundal varices were found in advanced liver disease $(18 \%$ in advanced liver disease versus $0 \%$ in CTP-A, $p=0.01$ ) The most common endoscopic finding was esophageal varices $(n=93)$, followed by PHG in 33 patients. Less frequent findings included duodenal ulcers, esophageal ulcers, gastric ulcers and gastric erosions (Table-II).

\begin{tabular}{|c|c|c|c|c|c|}
\hline \multirow{2}{*}{\multicolumn{2}{|c|}{ Variables }} & \multirow{3}{*}{$\begin{array}{c}\begin{array}{c}\text { Total no. of } \\
\text { patients N (\%)* }\end{array} \\
38(23.0)\end{array}$} & \multicolumn{2}{|c|}{ Fundal Varices } & \multirow{2}{*}{$p$ value ${ }^{* \star *}$} \\
\hline & & & \multirow{2}{*}{$\begin{array}{c}\text { Present } \mathbf{n}(\%)^{* \star} \\
7(18.4)\end{array}$} & \multirow{2}{*}{$\begin{array}{c}\text { Absent n (\%) } \\
31(81.6)\end{array}$} & \\
\hline \multirow{4}{*}{ Age of patients } & $<40$ years & & & & \multirow{4}{*}{0.9} \\
\hline & $41-50$ years & $57(34.5)$ & $8(14)$ & $49(86)$ & \\
\hline & $51-60$ years & $46(27.9)$ & $6(13)$ & $40(87)$ & \\
\hline & $>60$ years & $24(14.5)$ & $4(16.7)$ & 20 (83.3) & \\
\hline \multirow{2}{*}{ Gender } & Male & $103(62.4)$ & $16(15.5)$ & $87(84.5)$ & \multirow{2}{*}{0.86} \\
\hline & Female & $62(37.6)$ & $9(14.5)$ & $53(85.5)$ & \\
\hline \multirow{4}{*}{$\begin{array}{l}\text { Cause of } \\
\text { Cirrhosis }\end{array}$} & Non-Viral & $14(8.5)$ & $3(21.4)$ & $11(78.6)$ & \multirow{4}{*}{0.85} \\
\hline & HBV & $17(10.3)$ & $2(11.8)$ & $15(88.2)$ & \\
\hline & HCV & $124(75.2)$ & $18(14.5)$ & $106(85.5)$ & \\
\hline & HBV \& HCV & $10(6.1)$ & $2(20)$ & $8(80)$ & \\
\hline \multirow{2}{*}{$\begin{array}{l}\text { Stage of Liver } \\
\text { Disease }\end{array}$} & Compensated (CTP-A) & $27(16.4)$ & $0(0)$ & $27(100)$ & \multirow[b]{2}{*}{0.01} \\
\hline & Decompensated (CTP-B/C) & $138(83.6)$ & $25(18.1)$ & $113(81.9)$ & \\
\hline
\end{tabular}

Table-I. Demographic data of studied cirrhotic patients and factors associated with bleeding fundal varices "percentage shown along the column for that category ${ }^{* *}$ percentage shown across the row ${ }^{* * *} \mathrm{p}<0.05$, significant 


\begin{tabular}{|c|c|}
\hline \multicolumn{1}{|c|}{ Esophageal Varices } & $93(56.4)$ \\
\hline Gastropathy & $33(20)$ \\
\hline Fundal Varices & $25(15.2)$ \\
IGV-1 & 15 \\
GOV-2 & 10 \\
\hline Duodenal Ulcers & $6(3.6)$ \\
\hline Esophageal Ulcers & $5(3.0)$ \\
\hline Gastric Ulcers & $2(1.2)$ \\
\hline Gastric Erosions & $1(0.6)$ \\
\hline Table-II. Endoscopic findings of AUGIB cirrhotic \\
patients n(\%) \\
\hline
\end{tabular}

\section{DISCUSSION}

The demographic analysis of our study revealed that AUGIB is much more common in male cirrhotic patients as compared to female patients $(62.4 \%$ versus $37.6 \%, p<0.0001)$ and this is compatible with many other studies. ${ }^{13,14,15,16}$

Mean age at presentation in some studies is around $65-70$ years. ${ }^{17,18}$ In contrast to these studies mean age of cirrhotic patients presenting with AUGIB in our study was 50.15 years. This may be explained by the fact that viral liver disease is much more prevalent in our younger population. Our results are somewhat compatible to four studies: Romcea et al. ${ }^{13}$, Svoboda et al. ${ }^{19}$, GonzálezGonzález et al ${ }^{20}$, and Gabr et $a .^{16}$ (56.76, $56.9,56.5$ and 58.57 years old, respectively). The vast majority $(75 \%)$ of cases of cirrhosis were due to HCV, which was comparable to some ${ }^{16}$, however it contradicts the many western studies in which alcohol is the most common cause of cirrhosis. ${ }^{19,20,21,22}$

Majority (83\%) of our cirrhotic patients with AUGIB have advanced liver disease (CTP B or $\mathrm{C}$ ), indicating that severity of disease is a risk factor for AUGIB. Several studies report similar results. 14,15,16,19,23 Bleeding esophageal varices was the most common endoscopic finding, which was consistent with most other studies ${ }^{16}$ Three western studies ${ }^{21,23,24}$ found PHG as the most common non-variceal cause of bleeding, which is similar to our study. Different studies found gastric varices ranging from $8.3 \%$ to $9.4 \% .{ }^{13,16}$ However these figures did not quantify the frequency of pure fundal varices (IGV-1 and GOV-2). Our study shows a higher frequency of bleeding fundal varices $(15 \%)$ and statistically significant $(p<0.05)$ association with advanced liver disease.

\section{CONCLUSION}

AUGIB is more common in males and advance liver disease. Our study showed that $15 \%$ of AUGIB in cirrhosis is due to bleeding fundal varices (IGV1 and GOV-2) and they have a strong association with advanced liver disease. The prevalence of fundal varices is quite a high in Southern Punjab as compared to other parts of the world. The main limitation to this study was that the sample size was small and it was a single centre study. More studies need to performed so as to validate the increased prevalence of fundal varices in cirrhotic patients in this part of the world.

Copyright $\odot 15$ June, 2019.

\section{REFERENCES}

1. Nobel J, Louis St. Textbook of primary care medicine. 3rd edition. Mosby; 2001. Gastrointestinal haemorrhage; pp. 991-999.

2. Hopper AD, Sanders DS. Upper GI bleeding requires prompt investigation. Practitioner. 2011; 255(1742):1522.

3. Palmer KR. British society of gastrointestinal endoscopy committee: Non-variceal upper gastrointestinal haemorrhage: Guidelines. Gut. 2002; 51(Suppl4):iv1-iv6.

4. Gilbert DA Epidemiology of upper gastrointestinal bleeding. Gastrointest Endosc. 1990 Sep-Oct; 36(5 Suppl):S8-13.

5. Hearnshaw SA, Logan RF, Lowe D, Travis SP, Murphy MF, Palmer KR Acute upper gastrointestinal bleeding in the UK: Patient characteristics, diagnoses and outcomes in the 2007 UK audit. Gut. 2011 Oct; 60(10):1327-35.

6. Amitrano L, Guardascione MA, Manguso F, Bennato R, Bove A, DeNucci C, Lombardi G, Martino R, Menchise $A$, Orsini L, Picascia S, Riccio $E$. The effectiveness of current acute variceal bleed treatments in unselected cirrhotic patients: Refining short-term prognosis and risk factors. Am J Gastroenterol. 2012 Dec; 107(12):1872-8.

7. Wilcox CM, Cryer BL, Henk HJ, Zarotsky V, Zlateva G. Mortality associated with gastrointestinal bleeding events: Comparing short-term clinical outcomes of patients hospitalized for upper GI bleeding and acute myocardial infarction in a US managed care setting. Clin Exp Gastroenterol. 2009; 2():21-30. 
8. Tsao-Garcia G. Carey W and the practice guidelines committee of the Association for the Study of Liver Disease, the practice parameters committee of the American College of Gastroenterology. Prevention and management of gastroesophageal varices and variceal hemorrhage in cirrhosis. Hepatology. 2007;46:922-38.

9. Villanueva $C$, Piqueras M, Aracil C, Gómez C, LópezBalaguer JM, Gonzalez B, Gallego A, Torras X, Soriano $G$, Sáinz $S$, Benito $S$. A randomized controlled trial comparing ligation and sclerotherapy as emergency endoscopic treatment added to somatostatin in acute variceal bleeding. Journal of hepatology. 2006 Oct 1;45(4):560-7.

10. Abraldes JG, Villanueva $C$, Bañares R, Aracil C, Catalina MV, Garci A, Pagán JC, Bosch J. Spanish Cooperative Group for Portal Hypertension and Variceal Bleeding. Hepatic venous pressure gradient and prognosis in patients with acute variceal bleeding treated with pharmacologic and endoscopic therapy. J Hepatol. 2008 Feb;48(2):229-36.

11. Bosch J, Thabut D, Albillos A, Carbonell N, Spicak J, Massard J, D'Amico G, Lebrec D, de Franchis R, Fabricius $S$, Cai Y. Recombinant factor VIla for variceal bleeding in patients with advanced cirrhosis: a randomized, controlled trial. Hepatology. 2008 May;47(5):1604-14.

12. Sarin SK, Lahoti D, Saxena SP, Murthy NS, Makwana UK Hepatology. 1992 Dec; 16(6):1343-9.

13. Romcea A, Tanttau M, Seicean A, Pascu O. The etiology of upper gastrointestinal bleeding in cirrhotic patients. Clujul Med. 2013; 86: 21-3.

14. Seo $Y, \operatorname{Kim} Y$, Ahn $S$, et al. Clinical features and treatment outcomes of upper gastrointestinal bleeding in patients with cirrhosis. J Korean Med Sci. 2008; 23:635-43.

15. Odelowo OO, Smoot DT, Kim K. Upper gastrointestinal bleeding in patients with liver cirrhosis. $\mathrm{J}$ Natl Med Assoc. 2002; 94:712-5.

16. Gabr MA, Tawfik MA, El-Sawy AA. Non-variceal upper gastrointestinal bleeding in cirrhotic patients in Nile Delta. Indian J Gastroenterol DOI 10.1007/s12664-0160622-7
17. Van Leerdam ME, Vreeburg EM, Rauws EA, et al. Acute upper GI bleeding: Did anything change? Time trend analysis of incidence and outcome of acute upper GI bleeding between 1993/1994 and 2000. Am J Gastroenterol. 2003; 98:1494-9.

18. Di Fiore $F$, Lecleire $S$, Merle $V$, et al. Changes in characteristics and outcome of acute upper gastrointestinal hemorrhage: A comparison of epidemiology and practices between 1996 and 2000 in a multicenter French study. Eur J Gastroenterol Hepatol. 2005; 17:641-7.

19. Svoboda P, Konecny M, Martinek A, Hrabovsky V, Prochazka V, Ehrmann J. Acute upper gastrointestinal bleeding in liver cirrhosis patients. Biomed Pap Med Fac Univ Palacky Olomouc Czech Repub. 2012; 156:266-70.

20. González-González JA, García-Compean D, VázquezElizondo G, Garza-Galindo A, Jáquez-Quintana JO, Maldonado-Garza H. Nonvariceal upper gastrointestinal bleeding in patients with liver cirrhosis. Clinical features, outcomes and predictors of in-hospital mortality. A prospective study. Ann Hepatol. 2011; 10:287-95.

21. Schafer E, Rusznyak K, Visnyei $Z$, et al. Upper gastrointestinal bleeding in patients with cirrhosis. $Z$ Gastroenterol. 2011; 49:A76.

22. Bambha K, Kim WR, Pedersen R, Bida JP, Kremers WK, Kamath PS. Predictors of early re-bleeding and mortality after acute variceal haemorrhage in patients with cirrhosis. Gut. 2008; 57:814-20.

23. D'Amico G, De Franchis R, Cooperative Study Group. Upper digestive bleeding in cirrhosis. Posttherapeutic outcome and prognostic indicators. Hepatology. 2003; 38:599-612

24. Constantin V, Socea B, Popa F, et al. Epidemiological aspects and risk factors in the outcome of variceal eso-gastric bleeding at cirrhosis patients. JAQM. 2008; 3:316-24. 


\begin{tabular}{|c|l|l|}
\multicolumn{4}{|c|}{ AUTHORSHIP AND CONTRIBUTION DECLARATION } \\
\hline Sr. \# & \multicolumn{1}{|c|}{ Author-s Full Name } & \multicolumn{1}{|c|}{ Contribution to the paper } \\
\hline 1 & $\begin{array}{l}\text { Waseem Sarwar } \\
\text { Malghani }\end{array}$ & $\begin{array}{l}\text { Study concept, design, data } \\
\text { collection, interpretation of results. } \\
\text { Data collection, Design, } \\
\text { Interpretation of results, Writing. } \\
\text { Data collection, Drafting, Writing. }\end{array}$ \\
\hline 2 & $\begin{array}{l}\text { Farooq Mohyud Din } \\
\text { Chaudhary } \\
\text { Asim Tameez Ud Din }\end{array}$ \\
\hline 4 & $\begin{array}{l}\text { Sana Mohyud Din } \\
\text { Chaudhary }\end{array}$ & Data collection, Writing. \\
\hline 5 & Asma Tameez Ud Din & Data collection, Writing. \\
\hline
\end{tabular}

